\title{
A Comparative Study on the Training Programs of Chinese and Russian Sports Doctoral Students
}

\author{
Maosen Guan ${ }^{1, *}$ Huawei Wang ${ }^{2}$ Mengqi Li $^{2}$
}

\author{
${ }^{1}$ Krasnoyarsk State Pedagogical University Named After V. P. Astafev, ul. A. Lebedevoy, 89, Krasnoyarsk 660060, \\ Russian Federation \\ ${ }^{2}$ Russian State University of Physical Culture, Sports, Youth and Tourism, Lilac Boulevard, building 4, K1, Mосква \\ 105122, Russia. \\ *Corresponding author.
}

\begin{abstract}
The training program of sports doctor in Russia is of great significance to the construction and reform of the theoretical system of the training program of sports doctor in China in the new period and to guide the training and development of sports doctor in China. Through literature method, comparison method and on-the-spot investigation method, this paper makes a comparative analysis of the professional setting, training objective, training mode, course setting, credit and class hours of the research and training of Ph. D. in physical education in the "Two Schools" (the Two Schools refer to the School of Physical Education and Health, Krasnoyarsk State Teachers' University, Russia and the School of Physical Education and Sport, Henan University, China; and they are hereinafter referred to as the "Two Schools"). The results show that: First, in terms of sports professional setting, China has more extensive fields and more professional directions, while in Russia, sports professional setting is more specific and refined. Second, there is a certain degree of similarity in their cultivation objectives; both countries attach great importance to the training of educational teachers and scientific research personnel. Third, the training methods of the two countries are basically the same in terms of learning. In the training program of Russia, there is no explicit requirement of "learning knowledge of other subjects". Although there are abundant settings in such subjects, there is a lack of supervision measures in the training program of sports doctor. Fourth, China attaches great importance to professional theoretical courses and the cultivation of students' professional theoretical knowledge, while less curriculum of professional theory is set in Russia. Fifth, the class hours of Ph. D. in Physical Education in China are significantly less than those in Russia. Therefore, the service scope and work direction of the research field should be clearly defined, and the class hours should be appropriately increased.
\end{abstract}

Keywords: China, Russia, doctor of physical education, cultivation plan, the comparative study

\section{INTRODUCTION}

A $\mathrm{PhD}$ is the highest level of academic education, so how to carry out the "education"? This problem is the paramount issue to be solved. In the education system, as for the issue of how to educate the students, the first step is to make a "learning programs" for the students. Learning programs are also called "training programs" or "training plans" in the educational system. The development of training program is to develop different training objectives according to different majors. The training program mainly includes the following elements: major setting, training goal, length of schooling and years of study, training mode, curriculum setting, etc.
China's doctoral training from the 1950s. China once built and implemented the cultivation system of Associate Doctoral candidate (Кандидат наук) ${ }^{1}$, which was introduced from the Soviet Union. A considerable number of Chinese students in Soviet Union have obtained associate doctorate degrees. But this system was abolished soon after it was

Associate doctor (Кандидат наук) is short for the "Associate Doctor of Science", which is the degree lower than Doctor of Science in the two-level degree set by the Soviet Union. The associate degree "is usually awarded to the candidate who has received the required postgraduate education or has equivalent educational level and has passed the associate degree examination and defended his/her dissertation (work) in accordance with the regulations". See Gu Mingyuan. Dictionary of Education, Shanghai Education Press, 1998, p. 881. 
implemented in New China [1]. From this it can be seen that the embryonic form of doctoral research education in China originated from Russia. Over time, the cultivation of Russian associate $\mathrm{PhD}$ students has changed. Now in the training of associate doctoral candidate of sports in Russia, after consulting relevant literature, the author finds that the research on the system and training scheme of associate doctoral candidate in sports in Russia is rare. Based on this, the author believes that it is necessary to make a comparative analysis of the research and training programs of Sports doctor in China and Russia, and find out the training gap between the two countries, so as to provide reference for the construction and reform of the theoretical system of China's sports doctor training program in the new era and guide the training and development of China's sports doctor.

\section{THE DEVELOPMENT STATUS OF CHINESE AND RUSSIAN DOCTORAL STUDENTS}

\section{A. The background and current situation of doctoral education in China}

The development of doctoral research education in China can be divided into three stages: learning from the Soviet Union to establish the training mechanism of deputy doctoral students — abolishing the training mechanism of associate doctoral students establishing the training mechanism of doctoral students. The above three stages are described as follows:

1) Learning from the Soviet Union to establish the training mechanism of associate doctoral students: After the founding of New China, facing the international environment of confrontation between the two camps in the world, the Central People's Government established the foreign policy of "onesidedness", put forward the slogan of "learning from the Soviet Union" in the development of education, abandoned the degree system under the Kuomintang rule, and began to learn from the Soviet Union's experience in postgraduate education. On August 5, 1955, the 17th plenary Meeting of the State Council discussed and adopted the "Provisional Regulations on Graduate Students of the Chinese Academy of Sciences", which were promulgated and implemented on August 31. It marks the preliminary establishment of the associate doctor (Кандидат наук) training system in Chinese Academy of Sciences. The regulations are also the first formal postgraduate training system in New China.

2) Abolishing the training mechanism of associate doctoral students: On March 25, 1957, the Ministry of Higher Education issued a notice to cancel the title of "associate doctoral candidate", collectively referred to as graduate students, and the length of schooling for graduate students was unified from 4 years to 3 years. On May 17 of that year, the Ministry of Higher Education explicitly issued a notice, clearly stipulating that no associate doctoral dissertation defense would be held, and no associate doctoral degree would be awarded. The attempt to establish an associate doctor's degree was thus stopped.

3) Establishing the training mechanism of doctoral students: Academic Degrees Committee of the State Council of China was founded on December 5, 1980. In accordance with the "Regulations", the Committee has improved the educational system for master's and doctor's degree candidates and promulgated the "Principles and Methods of the Academic Degrees Committee of the State Council on the Examination and Approval of Degree-conferring Units" (February 24, 1981) and the "Interim Measures for the Implementation of the Regulations of the People's Republic of China on Academic Degrees" (May 20, 1981). Accordingly, the Ministry of Education revised and supplemented the provisional Regulations on the Work of Cultivating Postgraduates in Institutions of Higher Learning", and issued a series of supplementary regulations and notices. Thus, the academic degree system was closely combined with the postgraduate education system, and a supporting system of academic degree and postgraduate education was initially formed. In 1982, the work of recruiting doctoral students began.

\section{B. The development and current situation of doctoral students in Russia}

The development of doctoral research education in Russia can be divided into two stages: first, the cultivation of associate doctoral students in the Soviet Union period (the October Revolution in 1917 - the collapse of the Soviet Union in 1991); second, the cultivation of associate doctoral candidate in the Russian Federation period (collapse of the Soviet Union in 1991 - present). Elaboration will be made on these two aspects as follows:

1) The cultivation of associate doctoral students in the Soviet Union period: In 1925, the People's Ministry of Education of the Soviet Union passed the "Regulations on Training Scientific Cadres in Institutions of Higher Learning and Scientific Research Institutions", which clearly stipulated the establishment of the "Graduate Department". Students studying and training in the Graduate Department were called "graduate students" and their study period was three years.

In 1934, the People's Ministry of Education of the Soviet Union promulgated and unanimously adopted 
the "Decision on Academic Degrees and Academic Titles" (hereinafter referred to as the "Decision"). The "Decision" adopted the establishment of a two-level degree consisting of "Associate Doctor of Science" (Кандидат наук)" and "Doctor of Science (Доктр наук)". In addition, it also stipulated that relevant academic titles, including professor, associate professor, assistant professor and so on, shall be set up in teaching posts of institutions of higher learning, while academic titles set up in scientific research institutions shall include academician and researcher (senior and junior) and so on.

In the development of postgraduate education in the Soviet Union period, the Highest Academic Degree Evaluation Committee (hereinafter referred to as "ВАК": Высшая аттестационная комиссия, Высший аттестационный комитет) plays an indispensable role. In 1975, in order to ensure the consistency of the evaluation and requirements of high-level cadres, the Soviet Union approved and promulgated the "Regulations of the Supreme Academic Degree Assessment Committee" and the "Regulations on the Awarding of Academic Degrees" (hereinafter referred to as the "Regulations"). The "Regulations" stipulated the "BAK" is a national body of the Union, reorganized from the Supreme Academic Degree Assessment Committee of the Ministry of Higher and Secondary Professional Education of the Soviet Union; its main responsibilities include: to be responsible for the evaluation of high-level scientific research and education personnel, to formulate unified requirements for academic degrees and academic titles, and to test the quality of academic dissertations, etc.

2) The cultivation of associate doctoral candidate in the Russian Federation period (collapse of the Soviet Union in 1991 - present): After the collapse of the Soviet Union in December 1991, Russia, as the largest federal state, undoubtedly inherited the most important educational resources of the Soviet Union. In March and April 1992, the Ministry of Education and Science of the Russian Federation adopted, respectively, the "Resolution on the Multi-level Structure of Higher Education in the Russian Federation" and the "Provisional Regulations on the Multi-level Structure of Higher Education in Russia". In June 1999, the "Bologna Declaration" was adopted to establish a "European Higher Education Area" with the aim of establishing a unified degree, obtaining equivalent certifications, promoting the integration of European higher education and enhancing the influence of the EU in international education competition. According to the declaration, the main tasks of all countries before 2010 are to establish an easily understood and comparable academic degree system, to implement a two-level undergraduate and postgraduate education system, to establish a credit system, to promote teacher-student and academic exchanges, to ensure the level of higher education in Europe, and to promote educational cooperation within Europe. From the current academic degree system in Russia (bachelor-master-associate doctor-doctor) and the academic degree system implemented in the Soviet Union (expert-associate doctor-doctor), it is not difficult to see that Russia is more influenced by the "Bologna Declaration", and its current academic degree system is more in line with the international academic degree system.

\section{RESEARCH OBJECT}

The doctoral students' education and training in School of Physical Education and Health, Krasnoyarsk State Teachers' University, Russia and the School of Physical Education and Sport, Henan University, China are studied.

\section{A COMPARATIVE STUDY ON THE TRAINING PROGRAMS OF CHINESE AND RUSSIAN SPORTS DOCTORAL STUDENTS}

\section{A. Major setup}

Majors are set up to meet the need for training in a certain social profession. The setting of PE major is the important basis of the training type, specification and direction of PE talents, and the important basis of PE curriculum and discipline construction. It also reflects a country's actual and potential demand for sports talents, which is closely related to the development of the country's comprehensive national strength and the development level of sports undertakings.

According to the investigation, the doctoral candidates of the School of Physical Education and Sport, Henan University were set up according to the "Catalogue of Disciplines and Specialties for Awarding Doctor's and Master's Degrees and Training Postgraduate Students" jointly issued by the Academic Degrees Committee of the State Council and the State Education Commission in June 1997 and the Catalogue of Disciplines and Specialties for Awarding Doctor's and Master's Degrees and Training Postgraduate Students issued by the Academic Degrees Committee of the State Council and the State Education Commission in December 2005 (amended and supplemented for the second time). The establishment of doctor graduate majors in Henan University was also carried out according to this directory. In 2005, the school was authorized to grant doctor's degree in Physical Education and Training (a second-level discipline authorized unit), and in 2018, we were authorized to grant the first-level discipline Sports Science. In other words, the school was approved as a first-level discipline authorization unit and can recruit 
students in all second-level disciplines under it. According to the catalogue, there are four secondary disciplines under Sports Science, namely Physical Education Training, Sports Humanistic Sociology, Human Movement Science and Science of Ethnic Traditional Sports.

The School of Physical Education and Health, Krasnoyarsk State Teachers' University, Russia has only one class of "theory and methodology of physical education, physical training, health and adaptive physical Education". The results of these studies will be based on the expansion of physical education, sports, health and adaptive sports research to strengthen its professional applications.

TABLE I. MAJOR SETTINGS FOR DOCTORAL CANDIDATES OF PHYSICAL EDUCATION IN THE "Two SCHOOLS"

\begin{tabular}{|c|c|c|}
\hline Nationality & $\begin{array}{c}\text { Discipline } \\
\text { code }\end{array}$ & Specialties \\
\hline \multirow{4}{*}{ China } & \multirow{4}{*}{0403} & Sports Humanistic Sociology \\
\hline & & Human Movement Science \\
\hline & & Physical Education Training \\
\hline & & Science of Ethnic Traditional Sports \\
\hline Russia & 49.06 .01 & $\begin{array}{l}\text { Theories and methods of physical education, athletic training, health care and adapted } \\
\text { physical education* } \\
\text { (Теория и методика физического воспитания, спортивной тренировки, } \\
\text { оздоровительной и адаптивной физической культуры 13.00.04) }\end{array}$ \\
\hline
\end{tabular}

a. *Note: The translation of professional name comes from the Chinese Service Center for Scholarly Exchange, "Foreign Education and Degree Recognition Certificate"

Although both China and Russia rely on platforms of comprehensive universities, it can be seen from "Table I" that China and Russia show significant differences in specialty setting. The differences are mainly shown in two aspects. First, compared with Russia, China has more extensive fields and more professional directions in the setting of sports majors, which has changed from the "sports type" professional talent cultivation in the past to the "comprehensive sports type" professional talent cultivation across disciplines. Especially since the beginning of the 21 st century, with the more extensive demand for sports in China, many new majors have emerged. For example, the sports tourism major, Traditional Chinese Medicine sports major, sports performance major, broadcasting and hosting art major, stadium security major, sports music major, sports advertising and design major are mostly emerging majors in the world. Second, compared with Russia, the setting of sports majors in China is too "comprehensive", which tends to lead to unclear professional training objectives, unclear training specifications, and repeated course setting among different majors, resulting in "unspecialized" talent training. But the setting of sports majors in Russia is more specific and refined, and the training objectives and professional connotation can be seen directly from the names.

\section{B. Training objective}

The training objective of China's doctoral students in physical education is to train high-level professionals in the field of science who are morally, intellectually and physically well-developed, full of innovative spirit and practical ability. They should have international vision, foreign language, computer and other information skills, and have the ability to independently engage in creative sports scientific research, teaching or social service work. They should also master the solid and broad basic theories and systematic and in-depth specialized knowledge of the subject and the skills and methods of sports science research.

The training objectives of Russian associate doctoral students in sports is to cultivate expert hightech and applied talents who can carry out creative physical activities and have high-level physical research and physical education ability as well as broad scientific and cultural vision.

The training objectives of $\mathrm{PhD}$ students in the two countries are similar to a certain extent. Both countries attach great importance to the training of educational teachers and scientific research personnel. At present, the education and training of doctoral students in Russia is more oriented towards the cultivation of applied talents, with the purpose of cultivating them into highlevel research talents; more extensive in content as it presents, China still focuses on theoretical research, with the same purpose of cultivating them into highlevel research talents.

\section{Training mode}

The training methods of ph. D. students in physical education in the School of Physical Education and Sport, Henan University mainly include the following aspects. First, systematic theoretical learning, scientific research and practical activities are be adopted in learning. Centering on scientific research, the focus is on the cultivation of doctoral students' independent and creative research ability, the knowledge of other disciplines will be systematically learnt according to research needs. Second, the supervisor responsibility system is adopted for the cultivation of doctoral 
students. The main tasks of the supervisor are: carrying out ideological education for doctoral students; developing the course study plan and scientific research work plan for doctoral students; organizing and implementing training plan. Third, The tutor and the graduate students shall work out the personal training plan together and submit it to the graduate student office of the School of Physical Education and Sport for the record.

The School of Physical Education and Health, Krasnoyarsk State Teachers' University is basically the same as Henan University in terms of learning. However, in the training program of Krasnoyarsk State Teachers' University, "learning knowledge of other subjects" has not been made clear. The system of supervisor responsibility and the main tasks of supervisors in doctorate students cultivation lead to the same destination. Consistent methods are taken in terms of learning plans. While there is no plan supervision mechanism in the training program of Henan University, there is a supervision mechanism in the
School of Physical Education and Health, Krasnoyarsk State Teachers' University, which requires a report in the teaching and research office of the school every semester, a report in the school every academic year, and an expert review group to evaluate the work and learning situation of tutors and doctoral students.

\section{Length of schooling, years of study and curriculum setting}

The length of schooling, years of study and curriculum setting for doctoral students of physical education in China and Russia are important components of school education and important ways to enhance physical health, develop academic level and scientific research methods, and train high-level outstanding scientific research personnel. The length of schooling, years of study and curriculum for doctoral students in all countries are mandatory and long-term, and the quality of them has a great influence on the realization of training objectives.

TABLE II. LENGTH OF SCHOOLING AND PERIOD OF STUDY FOR DOCTORAL STUDENTS IN PHYSICAL EDUCATION IN THE TWO SCHOOLS

\begin{tabular}{|c|l|l|l|l|}
\hline \multicolumn{1}{|c|}{ Length of schooling } & \multicolumn{1}{c|}{$\begin{array}{c}\text { Learning } \\
\text { time }\end{array}$} & $\begin{array}{c}\text { Years of } \\
\text { study }\end{array}$ & $\begin{array}{c}\text { Years of } \\
\text { working }\end{array}$ \\
\hline \multirow{2}{*}{ China } & Full-time & 3 & $3-8$ & 0 \\
\hline \multirow{2}{*}{ Russia } & Full-time (очная форма) & 3 & $3-7$ & 2 \\
\cline { 2 - 6 } & Part-time (заочная форма) & 4 & $4-7$ & 2 \\
\hline
\end{tabular}

It is not difficult to find from "Table II" that the doctoral students of physical education in the Two Schools are basically the same on the length of schooling - full-time, while the training mode of correspondence system is completely abolished in China. The length of schooling is 3 years and the maximum years of study are 8 years. Through the comparative analysis of the schools of the two countries in "Table III" and "Table IV" in terms of curriculum setting, it is found that the two countries have the same focus, yet show obvious differences. Similarities between them are: first, both countries pay more attention to the master of professional theoretical knowledge; second, the optional courses offered by the two majors are not limited to their own majors, covering a wide range of humanities, nature, society, biology and other majors; third, all countries attach great importance to courses such as foreign language, scientific research methods and applied thesis writing. Differences are reflected in: first, Russia offers courses such as Mental Health, Extremism Prevention, Team Science Training Guarantee and Scientific Training Management, while China offers ideological and political courses, such as Marxism and Contemporary China, Classics of Marx, Engels and Lenin, Academic Ethics, etc.; second, compared with Russia, China attaches more importance to professional theoretical courses and the cultivation of students' professional theoretical knowledge, while less curriculum of professional theory is set in Russia; third, there are practical courses in Russia, but not in China; fourth, the curriculum of $\mathrm{Ph}$. D. in physical education in China is significantly shorter than that in Russia. 
TABLE III. DOCTORAL CURRICUlum OF THE SCHOOL OF PHYSICAL EdUCATION AND SPORT, HENAN UNIVERSITY

\begin{tabular}{|c|c|c|c|c|c|c|c|}
\hline \multicolumn{3}{|c|}{ Course type } & course code & Course name & \multirow{2}{*}{$\begin{array}{l}\text { semester } \\
1\end{array}$} & \multirow{2}{*}{$\begin{array}{l}\text { credit } \\
\text { hour } \\
36\end{array}$} & \multirow{2}{*}{$\frac{\text { credit }}{2}$} \\
\hline \multirow{20}{*}{ 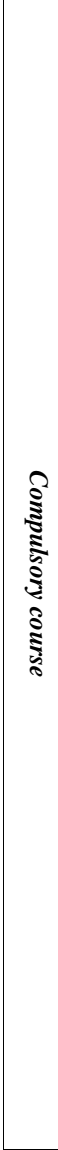 } & \multirow{3}{*}{\multicolumn{2}{|c|}{ public compulsory course }} & 0100711001 & English & & & \\
\hline & & & 0103011001 & Marxism and Contemporary China & 1 & 36 & 2 \\
\hline & & & 0100712002 & French & 1 & 36 & 2 \\
\hline & \multirow{17}{*}{$\begin{array}{l}\text { Professional } \\
\text { compulsory } \\
\text { course }\end{array}$} & \multirow{5}{*}{ All majors } & 1101814001 & $\begin{array}{l}\text { Introduction to Sports } \text { Science } \\
\text { Research }\end{array}$ & 1 & 36 & 2 \\
\hline & & & 1101814002 & Frontier of sports development & 1 & 18 & 1 \\
\hline & & & 1101814003 & Orientation Research Guide & 1 & 18 & 1 \\
\hline & & & 0101817001 & Academic Report & - & 20 & 1 \\
\hline & & & 0101817002 & Practical Links & 3 & 36 & 2 \\
\hline & & \multirow{3}{*}{$\begin{array}{l}\text { Sports Humanistic } \\
\text { Sociology }\end{array}$} & 1101814004 & $\begin{array}{l}\text { Special Topic on Sports Humanities } \\
\text { and Sociology }\end{array}$ & 2 & 36 & 2 \\
\hline & & & 1101814005 & $\begin{array}{l}\text { Special Topic on Sports Public } \\
\text { Service and Management }\end{array}$ & 2 & 18 & 1 \\
\hline & & & 1101814006 & Special Topic on Sports Economics & 2 & 18 & 1 \\
\hline & & \multirow{3}{*}{$\begin{array}{l}\text { Human Movement } \\
\text { Science }\end{array}$} & 110181407 & $\begin{array}{l}\text { Special Topic on Human Movement } \\
\text { Science }\end{array}$ & 1 & 36 & 2 \\
\hline & & & 110181408 & Molecular Biology & 2 & 18 & 1 \\
\hline & & & 110181409 & $\begin{array}{l}\text { Prevention and Treatment of Sports } \\
\text { Injuries and Rehabilitation }\end{array}$ & 2 & 18 & 1 \\
\hline & & \multirow{3}{*}{$\begin{array}{l}\text { Physical Education } \\
\text { Training }\end{array}$} & 1101814010 & $\begin{array}{l}\text { Special Topic on Physical Education } \\
\text { Theory }\end{array}$ & 1 & 36 & 2 \\
\hline & & & 1101814011 & Sports Training Monitoring Topics & 2 & 18 & 1 \\
\hline & & & 1101814012 & $\begin{array}{l}\text { Special Topic on Sports Competition } \\
\text { Theory }\end{array}$ & 2 & 18 & 1 \\
\hline & & \multirow{3}{*}{$\begin{array}{l}\text { Science of Ethnic } \\
\text { Traditional Sports }\end{array}$} & 1101814013 & $\begin{array}{l}\text { Overview of National Traditional } \\
\text { Sports }\end{array}$ & 1 & 36 & 2 \\
\hline & & & 1101814014 & History of Chinese Martial Arts & 2 & 18 & 1 \\
\hline & & & 1101814015 & $\begin{array}{l}\text { Comparison of Chinese and Western } \\
\text { Sports Culture }\end{array}$ & 2 & 18 & 1 \\
\hline \multirow{11}{*}{ 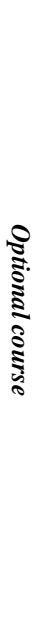 } & \multicolumn{2}{|c|}{ Public optional course } & 0103012001 & $\begin{array}{l}\text { Selected readings from the classics } \\
\text { of Marx, Engels and Lenin }\end{array}$ & 2 & 18 & 1 \\
\hline & \multirow{10}{*}{\multicolumn{2}{|c|}{ Professional optional course }} & 1101815001 & Special topic on sport philosophy & 2 & 18 & 1 \\
\hline & & & 1101815002 & Principles of Physical Education & 2 & 18 & 1 \\
\hline & & & 1101815003 & $\begin{array}{lll}\text { Sports } & \text { Literature } & \text { Information } \\
\text { Retrieval } & & \\
\end{array}$ & 2 & 18 & 1 \\
\hline & & & 1101815004 & Special Topic on Sports Sociology & 2 & 18 & 1 \\
\hline & & & 1101815005 & Sports Academic Ethics & 2 & 18 & 1 \\
\hline & & & 1101815006 & Science of Sport Law & 2 & 18 & 1 \\
\hline & & & 1101815007 & $\begin{array}{l}\text { Research Progress in Sports } \\
\text { Psychology }\end{array}$ & 2 & 18 & 1 \\
\hline & & & 1101815008 & $\begin{array}{l}\text { Special Topic on Industrial } \\
\text { Economics }\end{array}$ & 2 & 18 & 1 \\
\hline & & & 1101815009 & Sports Statistics & 2 & 18 & 1 \\
\hline & & & 1101814010 & $\begin{array}{l}\text { The Biological Basis of Physical } \\
\text { Activity }\end{array}$ & 2 & 18 & 1 \\
\hline
\end{tabular}

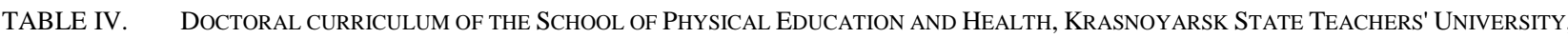
RUSSIA

\begin{tabular}{|c|c|c|c|}
\hline Course code & Course name & credit & $\begin{array}{l}\text { credit } \\
\text { hour }\end{array}$ \\
\hline \multicolumn{4}{|c|}{ public compulsory course } \\
\hline Б1.Б.01 & $\begin{array}{l}\text { History and Philosophy of Science } \\
\text { История и философия наук }\end{array}$ & 5 & 180 \\
\hline
\end{tabular}




\begin{tabular}{|c|c|c|c|}
\hline Course code & Course name & credit & $\begin{array}{l}\text { credit } \\
\text { hour }\end{array}$ \\
\hline \multicolumn{4}{|c|}{ public compulsory course } \\
\hline Б1.Б.02 & $\begin{array}{l}\text { Foreign languages } \\
\text { Иностранный язык }\end{array}$ & 4 & 144 \\
\hline Б1.В.01 & $\begin{array}{l}\text { Theories and Methods of Physical Education, Athletic Training, Health Care and Adapted } \\
\text { Physical Education } \\
\text { Теория и методика физического воспитания, спортивной } \\
\text { оздоровительной и адаптивной физической культуры }\end{array}$ & 3 & 108 \\
\hline Б1.В.02 & Methods of Writing Papers (Методика написания диссертации) & 2 & 72 \\
\hline Б1.В.03 & $\begin{array}{l}\text { The process of science and research innovation (Иссновационные процессы в науке и } \\
\text { научных исследованиях) }\end{array}$ & 2 & 72 \\
\hline Б1.B.04 & Fundamentals of Higher Education (Основы педагогики высшей школы) & 2 & 72 \\
\hline Б1.B.05 & Fundamentals of Advanced Psychology (Основы психологии высшей школы) & 2 & 72 \\
\hline Б1.В.ДВ.01 & Optional course Б1.В.ДВ.1 (Дисциплины по выбору Б1.В.ДВ.1) & 2 & 72 \\
\hline Б1.В.ДВ.01,01 & Fundamentals of Design Common Sense (Основы проектной грамотности) & 2 & 72 \\
\hline Б1.В.ДВ.01,02(-) & $\begin{array}{l}\text { Basic Computer Knowledge } \\
\text { Основы компьютерной грамотности }\end{array}$ & 2 & 72 \\
\hline Б1.В.ДВ.02 & $\begin{array}{l}\text { Optional Course Б1.В.ДВ.2 } \\
\text { Дисциплины по выбору Б1.В.ДВ.2 }\end{array}$ & 2 & 72 \\
\hline Б1.В.ДВ.02,01 & $\begin{array}{l}\text { Exercise Training Process Management } \\
\text { Управление спортивным тренировочным процессом }\end{array}$ & 2 & 72 \\
\hline Б1.В.ДВ.02,02(-) & $\begin{array}{l}\text { History of Sports Culture and Sports Education } \\
\text { История образования по физической культуре и спорт }\end{array}$ & 2 & 72 \\
\hline Б1.В.ДВ.03 & $\begin{array}{l}\text { Optional Course Б1.В.ДВ.3 } \\
\text { Дисциплины по выбору Б1.В.ДВ.3 }\end{array}$ & 3 & 108 \\
\hline Б1.В.ДВ.03,01 & $\begin{array}{l}\text { Fundamentals of Sports Psychology } \\
\text { Основы психологии спорта }\end{array}$ & 3 & 108 \\
\hline Б1.В.ДВ.03,02 & $\begin{array}{l}\text { Technical Terms for Higher Education } \\
\text { Речевая компетентность в высшей школе }\end{array}$ & 3 & 108 \\
\hline Б1.В.ДВ.04 & $\begin{array}{l}\text { Optional Course Б1.В.ДВ.4 } \\
\text { Дисциплины по выбору Б1.В.ДВ.4 }\end{array}$ & 3 & 108 \\
\hline Б1.В.ДВ.04,01 & $\begin{array}{l}\text { Providing Guarantee for the Scientific Training of the Team } \\
\text { Научно-методическое обеспечение подготовки сборных команд }\end{array}$ & 3 & 108 \\
\hline Б1.В.ДВ.04,02(-) & $\begin{array}{l}\text { Fundamentals of Sports Pedagogy } \\
\text { Основы спортивной педагогики }\end{array}$ & 3 & 108 \\
\hline \multicolumn{4}{|c|}{ 然 } \\
\hline Б2.В.01(П) & $\begin{array}{l}\text { Educational Practice } \\
\text { Педагогическая практика }\end{array}$ & 3 & 108 \\
\hline Б2.В.02(П) & $\begin{array}{l}\text { Scientific Research Practice } \\
\text { Научно-исследовательская практика }\end{array}$ & 3 & 108 \\
\hline \multicolumn{4}{|c|}{ Scientific research } \\
\hline Б3.В.01(H) & $\begin{array}{l}\text { Scientific Research Activities } \\
\text { Научно-исследовательская деятельность }\end{array}$ & 84 & 3024 \\
\hline Б3.B.02(H) & $\begin{array}{l}\text { Prepare for Evaluation of the Academic Thesis of the Associate Doctor's Degree } \\
\text { (dissertation) } \\
\text { Подготовка научно квалификационной работы(диссертации) на соискание ученой } \\
\text { степени кандидата наук }\end{array}$ & 45 & 1620 \\
\hline Б3.В.03(H) & $\begin{array}{l}\text { Symposium on Academic Subjects } \\
\text { Научно-исследовательский семинар }\end{array}$ & 6 & 216 \\
\hline \multicolumn{4}{|c|}{ National examination for admissions to the civil service } \\
\hline Б4.Б.01(Г) & $\begin{array}{l}\text { Preparing for national exams } \\
\text { Подготовка к сдаче и сдача государственного экзамена }\end{array}$ & 3 & 108 \\
\hline Б4.Б.02(Д) & $\begin{array}{l}\text { Submitting a research report on the main results of the academic paper prepared } \\
\text { (dissertation) } \\
\text { Представление научного доклада об основных результатах подготовленной научно- } \\
\text { квалификационной работы (диссертации) }\end{array}$ & 6 & 216 \\
\hline \multicolumn{4}{|c|}{ Optional course } \\
\hline ФТД.В01 & $\begin{array}{l}\text { "Extremism Prevention" Module } \\
\text { Модуль “профилактика экстреммзма" }\end{array}$ & 2 & 72 \\
\hline ФТД.В01,01 & $\begin{array}{l}\text { The Social Basis for Preventing Extremism and Dependency in the Context of Youth } \\
\text { Социальные основы профилактики экстремизма и зависимых форм поведения в } \\
\text { молодежной среде }\end{array}$ & 2 & 36 \\
\hline ФТД.В01,02 & $\begin{array}{l}\text { The Legal Basis for Preventing Extremism and Dependency in the Context of Youth } \\
\text { Правовые основы профилактики экстремизма и зависимых форм поведения в } \\
\text { молодежной среде }\end{array}$ & 1 & 36 \\
\hline ФТД.В01,03(К) & $\begin{array}{l}\text { The Extremism Prevention Test } \\
\text { Зачеты по модулю “профилактика экстремизма" }\end{array}$ & & \\
\hline
\end{tabular}




\section{CONCLUSION}

From the comparative study of the training programs of Chinese and Russian sports doctoral students, many traces of China's learning from the former Soviet Union can be found. In recent years, China and Russia have carried out timely reform on the training of doctoral students in physical education, which not only makes clear the orientation of levels, but also puts forward new requirements for the training of high-level sports talents. At the same time, obvious problems and differences are exposed through comparison.

First, in terms of the setting of sports majors, China has more extensive fields and more professional directions, while the setting of sports majors in Russia is more specific and refined. Second, there is a certain degree of similarity in cultivation objectives. Both countries attach great importance to the training of educational teachers, scientific research and scientific research personnel. Third, the training methods of the two countries are basically the same in terms of learning. Russia does make it clear that "students should learn knowledge of other disciplines" in the training program. With abundant settings in this aspect, though, there is a lack of supervision measures in the training program of sports doctor. Fourth, China attaches great importance to professional theoretical courses and the cultivation of students' professional theoretical knowledge, while less curriculum of professional theory is set in Russia. Fifth, the curriculum of $\mathrm{Ph}$. D. in physical education in China is significantly shorter than that in Russia. The service scope and working direction of the research field should be clarified, and the class hours should be increased appropriately.

\section{References}

[1] Li Peng. Historical Investigation on the Training System of Associate Doctoral Students in China [J]. Contemporary China History Studies, 2013, 20(03): 36-40+124. (in Chinese)

[2] Gu Mingyuan. Cultural Foundation of Chinese Education, Shanxi Education Press, 2004, page 231. (in Chinese)

[3] Luo Siming. China's Degree System: Problems and Countermeasures. Huazhong University of Science and Technology Press Co. Ltd, 2007, page 5. (in Chinese)

[4] Report of the Chinese Academy of Sciences on the Work of the Delegation to The Soviet Union [J]. Chinese Science Bulletin. 1954(04): 12-14. (in Chinese)

[5] Guo Jinhai. Regulation on early graduate students of Chinese academy of sciences [J]. Science Culture Review, 2009, 6(06): 82-98. (in Chinese)

[6] Summary and Work Plan of 1954 Office Meeting of Academic Secretariat of Chinese Academy of Sciences, 1st-29th (missing the 14th and 19th meetings). Archives of the Chinese Academy of Sciences, File No. 1954-22-2. (in Chinese)
[7] The Specific Steps of the Chinese Academy of Sciences on Adjusting and Changing the Institution of the Academy and the Organizational Form of the Academy, and the Report to the Central Committee After the Establishment of the Department. Archives of the Chinese Academy of Sciences. File No. 1955-14. (in Chinese)

[8] Higher Education Volume - Chinese Education Dictionary [M]. Shijiazhuang: Hebei Education Press, 1994: 581-582. (in Chinese)

[9] Yu Fuli, Pan Shaowei. (in Chinese) Comparative Analysis of Content Standards of Physical Education and Health Courses in China and the United States [J]. Journal of Sports and Science, 2011, (5): 107-110. (in Chinese)

[10] Liang Guoli, Gao Rong. Comparison of Physical Education Curriculum Standards in China and the United States - A Comparison of curriculum nature and design ideas [J]. Curriculum,Teaching Material and Method, 2004, (6): 91-95. (in Chinese) 